前腕骨々折 $の$ 治療

\begin{tabular}{|c|c|c|c|c|}
\hline 飯塚病院 & 整形外科 & 松 & 田 & 正 \\
\hline & & 加 & 藤 & 清 \\
\hline & & 松 & 隈 & 雄 \\
\hline
\end{tabular}

\title{
Treatment of Fractures of the Forearm
}

By

\section{S. Matsuda, K. Katō \& Y. Matsuguma}

Orthopedic clinic, Iizuka Hospital

昭和 29 年初より昭和 32 年 6 月末迄の 3 年半の間に 飯塚病院整形外科に於いて取扱つた前腕骨々折は 221 例であつた。我々の病院は炭坑地の中にある関係上, 保険別診療件数では労災の割合が多く, 特に他の部位 の骨折では労炎患者の割合が多くなつている。然し前 腕骨折にあつては（表 1) の様に幼児及び若年者が約 3 分の 2 を占めて打り, 労働年踚の者は比較的少くな つている。従つて保険別にあつては, 労災が少く保険 家族が多いことはその特改と云えよう。骨折の大部分

第 1 表 保險別, 年令別

\begin{tabular}{|c|c|c|c|c|c|c|}
\hline 年令 & 労災 & 健保 & 家族 & 國保 & その他 & 計 \\
\hline $0 \sim 10 才$ & 0 & 0 & 50 & 18 & 5 & 73 \\
\hline $11 \sim 20$ 才 & 8 & 5 & 31 & 12 & 23 & 79 \\
\hline $21 \sim 50$ 才 & 12 & 5 & 7 & 6 & 4 & 34 \\
\hline 50 才以上 & 3 & 0 & 15 & 14 & 3 & 35 \\
\hline 計 & 23 & 10 & 103 & 50 & 35 & 221 \\
\hline
\end{tabular}

第 2 表 原 因 别

\begin{tabular}{|c|c|c|c|c|}
\hline 原因 部位 & 近位端 & 骨幹部 & 末端部 & 計 \\
\hline 落 硬 & 0 & 1 & 1 & 2 \\
\hline はさむ & 1 & 4 & 5 & 10 \\
\hline 打 撜 & 4 & 14 & 20 & 38 \\
\hline 整 落 & 5 & 11 & 44 & 60 \\
\hline 轉 倒 & 11 & 29 & 75 & 115 \\
\hline 計 & 21 & 59 & 145 & 225 \\
\hline
\end{tabular}

が新鮮例で受傷後 1 ケ月以上の陳旧例は約 1 割であつ た。左右別では右側 95 例, 左側 130 例であつたが特 別な差異とは認められない。

受傷の原因は(表 2 )の様に, 転倒或は高所から落ち て手をついた時が最も多く，大部分が介達性の外力に よる為に開放骨折は極めて少く僅に 4 例に過ぎなかつ た。受傷直後の合併症としては, 上腕外顆骨折 3 例, 橈 骨神経麻㽻 2 例であつた。受傷後の治療中の合併症と して遠延治癒骨折は骨幹部骨折で 2 例, 橈骨未端骨折 で 1 例であり，ズデック急性骨萎縮は骨幹部骨折では 2 例, 橈骨末端骨折では 14 例に於いて認められた。 いずれも高跉者に多く, 少しく長期の治潦期間を要し 恢復はしたが幾分の可動制限を遺した。

第 3 表 近位端骨折

\begin{tabular}{|c|c|c|c|c|c|c|}
\hline \multirow{2}{*}{\multicolumn{2}{|c|}{$\begin{array}{l}\text { 年令 } \\
\text { 治潦 } \\
\end{array}$}} & \multicolumn{2}{|c|}{ 橈骨々折 } & \multicolumn{2}{|c|}{ 尺骨々折 } & \multirow{3}{*}{$\frac{\text { 計 }}{13}$} \\
\hline & & \multirow{2}{*}{$\frac{\text { 新鮮例 }}{1}$} & \multirow{2}{*}{$\frac{\text { 陳旧例 }}{0}$} & \multirow{2}{*}{$\frac{\text { 新鮮例 }}{11}$} & \multirow{2}{*}{$\frac{\mid \text { 陳旧例 }}{1}$} & \\
\hline \multirow{3}{*}{ 年 } & $0 \sim 10$ 术 & & & & & \\
\hline & $11 \sim 20$ 才 & 3 & 0 & 3 & 1 & 7 \\
\hline & $21 \sim 50 \mathrm{~J}$ & 1 & 0 & 0 & 0 & 1 \\
\hline \multirow[t]{2}{*}{ 令 } & 50 才以上 & 0 & 0 & 0 & 0 & 0 \\
\hline & 計 & 5 & 0 & 14 & 2 & 21 \\
\hline \multirow{2}{*}{$\begin{array}{l}\text { 治 } \\
\text { 療 }\end{array}$} & ギプス固定 & 4 & 0 & 14 & 2 & 20 \\
\hline & 手 術 & 1 & 0 & 0 & 0 & 1 \\
\hline
\end{tabular}

部位別に検討を試みるに, 近位端, 时関節部の骨折 に於いては（表 3）の如く，橈骨及び尺骨夫々の単独 骨折のみで両者骨折の合併した例はなかつた。その多 
〈は転位も少く 2 乃至 4 週間のギプス固定後関節の屈 伸運動訓練を強力に行い好結果を得た。手術例は 11 才の少女でとび箱から落ちて受傷したものであるが, 橈骨々頭の転位が著しい為, 受傷 2 日目に観血的骨接 合術を行つたものである。整復後キルシュナー釘固定 40 日にて抜釘後運動を行はしめ可動制限もなく治澺 を来すことが出来た。その他は骨折線が関節にか〉つ た例にあつても非観血的療法で殆ど正常な可動性にて 治瘉せしめることが出来た。

第 4 表 骨幹部 骨折

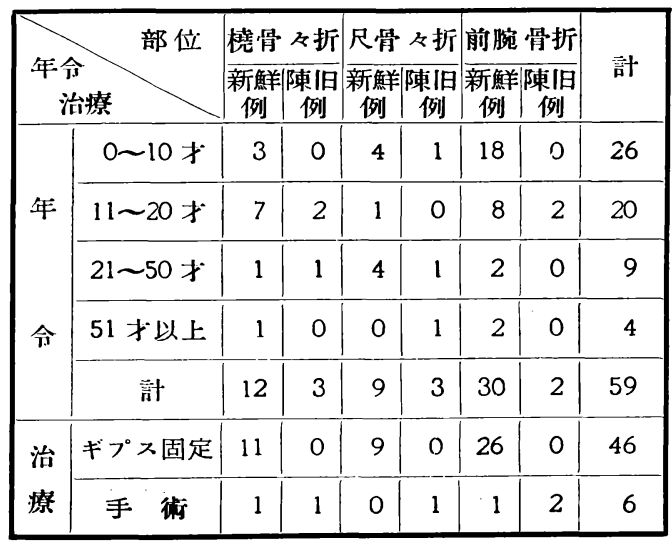

骨幹部骨折にあつては（表 4 ）の如くであるが，橈 骨及び尺骨夫々の単独骨折の場合は，転位の少いこと が多く，新鮮例にて手術を要したものは 1 例で，他は 4 週以内の固定で殆ど障害を遺さずに治癒している。 変形瘉合を来した症例では特に廻外運動の制限が著し く，観血的整復を要したが，手術後も迴内迴外運動は 可成りの制限が認められた。橈骨及び尺骨が両方とも 骨折を来した症例でも転位の少いものは短期間の固定 で十分であつたが，新鮮例にあつては徒手整復によつ て可成りの整復位を保持することが出来，新鮮例で手 術を要したものは 30 例 中 1 例のみであつた。陳旧例 で転位の著しいものは観血的手術の絶対的適応である が，この手術にあたり，キルシュナー釘或はキュンチ ヤー釘等による葡内固定は極めて便利で且つ有効であ つた。骨幹部の骨折治潦にあたつて特に注意を要する ことは迴内迴外運動の訓練で, 変形が遺ると此運動が 制限を受けるので矯正を十分にし，なるべく早期に十 分な運動訓練を行はしめるを要する。
第 5 表 末 端部骨折

\begin{tabular}{|c|c|c|c|c|c|c|c|c|}
\hline & \multicolumn{2}{|c|}{ 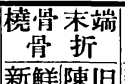 } & \multicolumn{2}{|c|}{$\begin{array}{c}\text { 尺骨末端 } \\
\text { 骨 折 }\end{array}$} & \multicolumn{2}{|c|}{\begin{tabular}{|l} 
前腕末端 \\
骨 折 \\
新鮮陳旧
\end{tabular}} & \multirow{2}{*}{ 計 } \\
\hline & & $\begin{array}{l}\text { 新鮮 } \\
\text { 例 }\end{array}$ & $\begin{array}{c}\text { 凍旧 } \\
\text { 例 }\end{array}$ & $\begin{array}{l}\text { 新鮮 } \\
\text { 例 }\end{array}$ & $\begin{array}{c}\text { 陳旧 } \\
\text { 例 }\end{array}$ & $\mid$ 新䱓 & $\begin{array}{c}\text { 陳旧 } \\
\text { 例 }\end{array}$ & \\
\hline \multirow{3}{*}{ 年 } & $0 \sim 10$ 术 & 33 & 1 & 0 & 0 & 2 & 0 & 36 \\
\hline & $11 \sim 20$ 才 & 46 & 0 & 3 & 0 & 4 & 0 & 53 \\
\hline & $21 \sim 50$ 才 & 19 & 4 & 0 & 0 & 1 & 0 & 24 \\
\hline \multirow[t]{2}{*}{ 令 } & 51 拟上 & 20 & 9 & 0 & 0 & 2 & 1 & 32 \\
\hline & 計 & 118 & 14 & 3 & 0 & 9 & 1 & 145 \\
\hline 治 & ギプス固定 & 110 & 5 & 3 & 0 & 8 & 0 & 126 \\
\hline 療 & 手 術 & 1 & 1 & 0 & 0 & 0 & 0 & 2 \\
\hline
\end{tabular}

前腕末端部の骨折にあつても（表 5 ）の如く殆どす ベては非観血的整復でよく効果をあげる事が出来た。 殊に幼児にあつては整復が完全でない場合でも 4〜5 週の固定後運動訓練により全く可動制限も見ずに治瘉 することが多かつた。成人の場合も整復は出来るだけ 厳密であることを要するが骨幹部骨折の時と同様に特 に迴内迴外運動に注意を要する。尺䯠端茎状突起の骨 折を合併した症例にあつては 3 例に於いて骨片の遊離 を認めたが，摘出は要しなかつた。骨転位や軟部損傷 の著しい時や高齡者の場合はズデック急性骨萎縮を来 寸事が多く、橈骨末端骨折で 14 例に見られた。此場合 各種注射投薬療法や理学療法も効果は少く従つて治療 に長期を要し多くは相等な関節の可動制限を遺した。 橈骨末端骨折の後遺症として著しいマーデルング様変 形を来した症例に於いて，尺骨短縮と同时に，その尺 骨から採取した骨片を利用しての橈骨延長を行い好結 果を得た症例があるが, 若年者にあつては出来るだけ 骨端線を損はない様に注意を要する。

\section{結语}

前腕骨折は若年者に多く，新鮮例にあつては観血的 整復を要することは少く，多くは徒手整復で良い結果 を得ることが出来る。徒手整復が困難なものや変形瘉 合骨折では観血的整復を要するがキルシュナー釗やキ ユンチヤー釘等の 髄内固定は極めて 便利で 効果が多 い。若年者では骨端線を出来るだけ損はぬよ5に注意 する必要がある。ズデック骨萎縮は治潦効果少く後障 害を遺すことが多い。後療法にあたつては肘及び腕関 節の届伸運動の他に特に迴内及び廻外運動訓練に注意 を要する。 